\title{
SENSITIVE RESPONSE AND RESISTANCE TO BERY DISEASE (Colletotrichum kahawae) OF TWO COFFEE VARIETIES (Coffea arabica AND C. canephora) : HISTOLOGICAL COMPARISONS OF INTERACTIONS
}

\author{
E.K.GICHURU \\ Coffee Research Foundation P O Box 4Ruiru 00232,Kenya. Email : ekgichuru@yahoo.com or crf@kenyaweb.com
}

\begin{abstract}
Seedling hypocotyls and attached green coffee berries of 11 Coffea arabica varieties and a Robusta coffee cultivar, with different levels of resistance to coffee berry disease (Colletotrichum kahawae), were examined under a microscope for differences in the development of infections caused by single-conidium isolates of the fungus and the response by the host tissu. As compared to susceptibility, resistance was characterised by fewer infection sites, slower and distorted fungal growth, as well as cytoplasmic changes in host cells. This resulted in plant cell death, hypersensitive reaction, pathogen death and the formation of scabs and cork barriers of various appearances. It was concluded that, under favourable environmental conditions, mechanisms that slow or hinder the activity of the pathogen in order to allowing full development of cork barriers, were the most important in determining resistance. The possibility of using types of scabs and barriers to discriminate between categories of host resistance and pathogen aggressiveness was suggested.
\end{abstract}

Key words : Colletotrichum kahawae, Coffee, resistant, susceptible, Kenya.

\section{RESUME}

SENSIBILITE ET RESISTANCE DU CAFE (VARIETES DU Coffea arabica ET C. canephora) A LA MALADIE DE FRUITS (Colletotrichum kahawae) : COMPARAISONS HISTOLOGIQUES DES INTERACTIONS

Le développement des infections causées par l'isolat issu d'un seul conidie de champignon et la réponse (ou les réactions) des tissus hôtes d'hypocotyles de " semence " et de "fruits verts » de 11 variétés de Coffea arabica, caractérisé par différents niveaux de résistance à la maladie des fruits (Colletotrichum kahawae) et d'un cultivar de Robusta, ont été étudiés au microscope photonique. Les résultats montrent que la résistance à la maladie caractérisée par : la réduction des sites d'infection, une croissance faible et anormale du champignon, des changements cytoplasmiques dans les cellules hôtes dus à la mort des cellules de la plante, suite à une réaction d'hypersensibilité, la mort des germes pathogènes et la formation de dépôts et d'appositions d'apparence variées. Dans les conditions environnementales favorables à la maladie, il apparaît que ces mécanismes qui freinent ou empêchent le développement du germe pathogène sont les plus importants dans la détermination de la résistance. La possibilité d'utiliser différents types de dépôts et d'appositions pour catégoriser la résistance des hôtes et l'agressivité du germe pathogène a été suggérée.

Mots clés : Colletotrichum kahawae, café, résistance, susceptibilité, Kenya.

\section{INTRODUCTION}

Infection of coffee berries by Colletotrichum kahawae is the cause of Coffee Berry Disease (CBD), which is a major limiting factor to economic production of Arabica coffee in Africa (Masaba and Waller, 1992). Most commercial
Arabica coffee cultivars are susceptible to the disease and have to be protected by intensive fungicidal sprays at susceptible stage (Griffiths et al., 1971). This is costly and not affordable to most coffee farmers. The use of CBD resistant cultivars provides a viable $C B D$ control alternative and, therefore, searching and breeding for resistance is of great importance. 
A breeding programme in Kenya was started in 1971, which lead to the development of the hybrid cultivar Ruiru 11, resistant to both CBD and leaf rust (Hemileia vastatrix). However, developping other resistance cultivars and broadening resistance base need to be continued to improve its expected durability. Knowledge of the mechanisms and characteristics of CBD resistance is important both in the development of disease resistant cultivars and in practical field management aspects, like the forecasting of disease epidemics. Many studies have been carried out in the past on the mechanisms of the resistance as reviewed by Gichuru (1997). These include structural, biochemical and escape factors, e.g. canopy microclimate. However, of particular reference to the work reported in this paper are the studies by Masaba and Van der Vossen (1982) on the histology of CBD lesions and that of Mwang'ombe and Shanker (1994) on the pre-penetration and sporulation stages of the pathogenesis. While the former dealt more with symptomatology, the later put more emphasis on the initial and final stages of the infection. This study aimed at providing additional and comparative microscopic information on the behaviour of pathogenic isolates of the fungus in the variable host responses.

\section{MATERIALS AND METHODS}

\section{COFFEE VARIETIES AND TISSUES}

Seedling hypocotyls and attached green expanding berries of eleven Coffea arabica varieties varying in $C B D$ resistance (K7, Caturra Amarillo, SL28, SL34, Catimor, Rume Sudan, Pretoria, Eritrean Mokka, Geisha 10, Mundo Novo), Robusta coffee (Coffea canephora) and the spontaneous inter-specific hybrid between C. arabica and C. canephora known as Hibrido de Timor (first discovered in the island of Timor ; Bettencourt, 1973) were used. Seedlings were raised by sowing seeds harvested from individual marked trees of the varieties on a moist and sterilised sand, as described by Van der Vossen et al. (1976).

\section{ISOLATES}

Coffee berries with active CBD lesions were collected from different coffee varieties growing in different areas in Kenya. After isolation of $C$. kahawae from each collection sample, several single conidium cultures were prepared per sample and tested for pathogenicity on detached green coffee berries of the susceptible variety SL28. One pathogenic single conidium culture was then randomly selected per sample and maintained on a $2 \%$ malt-extract agar (MEA, Oxoid, $2 \%)$ in a refrigerator, $\left(4-6^{\circ} \mathrm{C}\right)$. Before being used to inoculate tissues for the experiments, the cultures were rejuvenated by inoculation and re-isolation from detached green coffee berries of variety SL28. Unless stated, eight such cultures were used for the inoculation tests.

\section{INOCULATIONS}

Inoculation of both attached berries and hypocotyls was achieved through the modifications of the methods by Van der Vossen et al. (1976). Seedling hypocotyls were uprooted and arranged in plastic translucent lunch boxes with moistened cellulose wadding and another one used to cover the roots. Sections on the upper part (near the cotyledons) were limited by two marks with a felt pen about $5 \mathrm{~mm}$ apart. Drops of the inocula $\left(2 \times 10^{6}\right.$ conidia/ml) freshly prepared from 10-day-old cultures were spread along the marked sections carefully, using droppers avoiding run-off. Incubation was as described by Van der Vossen et al. (1976) but after three weeks at $18-20^{\circ} \mathrm{C}$, they were kept at room temperature $\left(20-24^{\circ} \mathrm{C}\right)$.

Green expanding berries (10 - 12 weeks after flowering) were inoculated on the trees in the field by placing drops of the inoculum on surface areas encircled with a ball point pen. These inoculations were done in the months of June and July when weather conditions were most suitable for CBD infection and no environmental modifications were done.

\section{MICROSCOPY}

Five seedlings or berries per isolate-variety combination were sampled weekly and the inoculated hypocotyls or pericarp tissues were sectioned using a Labline/Hooker plant microtome supported by insertion into carrot roots. When symptoms became visible, the samples were selected to include the whole range of visibly different symptoms. The sections were observed under light microscope either unstained mounted in distilled water or stained with Trypan blue in lactophenol. Sampling continued up to the eighth week after inoculation 
when further changes were minimal. The experiments were repeated at least twice. Microscope photographs of the sections were taken.

\section{RESULTS}

There were noticeable microscopic differences between the resistant and susceptible varieties one week after inoculation. In susceptible varieties, almost all the cells in the outermost two-cell layers below the inoculated area were infected unlike the resistant cultivars, where the infected, cells were few and limited to the outermost layers. The areas of successful infection were thus continuous in susceptible varieties but discrete in resistant ones. In susceptible varieties, the pathogen mycelia had grown up to 5 cells deep and the outer cells were browning while a few had collapsed, unlike the resistant cultivars, where the tissues were intact. No signs of infection were observed in tissues of Robusta coffee.

Various differences were observed between the extremes of susceptibility and resistance, within two to three weeks after inoculation with intermediate reactions. In susceptible reactions, lesions were visible as brown to black sunken areas but microscopic observation of the lesions from different varieties revealed some differences. In susceptible varieties, like SL28, SL34, Caturra Amarillo and some cases of Mundo Novo, Geisha 10, Eritrean Mokka and K7, there was sporulation and the mycelia had advanced deep into the tissues beyond necrotic areas. However, in most lesions on varieties with medium resistance like K7, Pretoria, Hibrido de Timor, Geisha 10, Mundo Novo and similar lesions in resistant varieties like Rume Sudan and Catimor, the hyphae were closer to the surface. Where hyphal growth was progressing, the advancing ends were just ahead of the area undergoing necrosis (Figure $1 \mathrm{~A}$ ). In susceptible reactions, the fast growing hyphae had longer thin-walled cells than in intermediate reactions, where hyphal growth was slower (Figures $1 \mathrm{~B}, \mathrm{C}$ ). In resistant reactions ranging from no macrosymptoms to small brown specks, no further growth of the hyphae was observed and usually the infected cells collapsed, suggesting hypersensitivity (Figure 1D).

In medium resistant and resistant varieties, there appeared within two to three weeks after inoculation, cells filled with dark granulated material at the periphery of the infected area (Figure $2 \mathrm{~A}$ ). There were differences in the continuity of these cells between cultivars such that in resistant varieties like Rume Sudan and Catimor, the cells usually formed a rather continuous border line while in medium resistant varieties there were fewer of these cells. Initiation of cork barrier formation occurred within this period beyond the dark cells, but this was observed even when these dark cells were absent (Figure $2 \mathrm{~B}$ ) and there were also cases of occurrence of these cells but without formation of cork. In cases where infection was arrested near the surface (1 - 3 cell depth), there was division of cells below this area to raise the infected tissue resembling type A scabs (Masaba and Van der Vossen, 1982). The size of these scabs depended on the number of infected cells. On attached Robusta coffee berries, there appeared brown crusts on the inoculated surfaces but the cells below them were not infected.

Between week 4 and 8 after inoculation, there was extensive necrosis, tissue disintegration and sporulation in susceptible ones but in resistant varieties necrosis was more restricted even when symptoms indicated susceptibility. Varieties with medium resistance had both types. In cases where the fungus developed on resistant varieties, cork barriers were mostly absent (Figure $3 \mathrm{~A}$ ) and if present they were rudimentary. However, the cell walls thickened and browned but without extensive necrosis. In resistant and medium resistant varieties, arresting of infection at advanced stages was characterised by formation of sunken type B barriers (Masaba and Van der Vossen, 1982). These developed fully within this period (4-8 weeks after inoculation). There was constriction and disappearance of the dark material cells leaving empty cells above the barrier, which developed further to comprise of 4 to 6 cell walls. The necrotic tissues tore off along the empty cells indicating they were dead (Figure $3 \mathrm{~B}$ ). A case was observed where an isolate of the pathogen grew through a developing cork barrier (Figure $3 \mathrm{C}$ ). Where type Abarriers were formed, they were less elaborate. These advanced reactions to infection were not observed in Robusta coffee where the most advanced infection was indicated by very small scabs (Figure $3 \mathrm{D})$.

The various reactions to infection occurred in various combinations both within and between cultivars and in isolates such that it was difficult 
to separate the two factors. Since sampling was destructive, it was not possible to determine durational dimensions like persistence of the dark cells or initiation and maturation of corks, because various stages were observed within the same sample. However, there were reactions characteristic of susceptible varieties when compared to resistant ones. These included high percentage of early infected cells, rapid and extensive tissue colonisation, lack of dark cells, lack of hypersensitivity and formation of type $B$ barriers if any were formed. Resistant varieties exhibited converse reactions and they mostly formed type A barriers. Intermediate reactions exhibited both types of corks in more or less equal proportions.

While most varieties exhibited similar reactions in both attached berries in the field and hypocotyls in the laboratory, it was observed that Geisha 10 had less infection points in the field and formed effective barriers as compared to laboratory inoculations. In the field, 120 infected berries of this variety had $30 \%$ active lesions, $27 \%$ type A barriers and $43 \%$ type B barriers. However in the laboratory, 120 infected hypocotyls had $81 \%$ active lesions, $3 \%$ type A barriers and $16 \%$ type $B$ barriers. The brown crusts formed on Robusta coffee berries in the field were not observed on hypocotyls in the laboratory.

Since it appeared that under favourable conditions for infection, type B barriers were formed when a resistant tissue is aggressively challenged or late resistance, an attempt was made to quantify possible inter-isolate and intervariety variations. Medium resistant and resistant varieties were used and inoculated with three isolates. Fifty hypocotyls per treatment, with inactive lesions were sectioned and observed at week 8 after inoculation when barriers were fully developed. The results are shown in Table 1, as the number of seedlings with fully developed type $B$ barriers. The remainder had mainly type $A$ corks, with few cases of rudimentary type B corks. It can be observed that in varieties Rume Sudan, K7 and Pretoria, isolate KM27 ranked the lowest. Rume Sudan had predominantly type A barriers, Geisha 10 and Mundo Novo had mainly type $B$, while the rest had high proportions of both types.
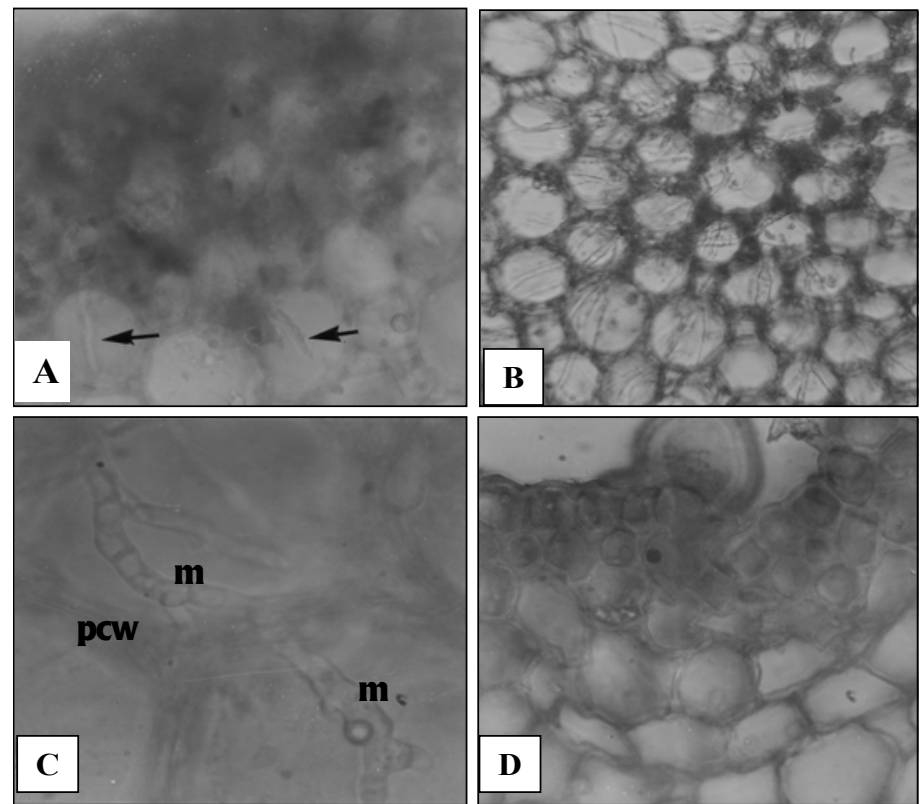

Figure 1 : Differences in hyphal growth and tissue colonisation.

\section{Différences de croissance mycélienne et de colonisation des tissus infectés.}

(A) Advancing hyphal tips close to surface tissue undergoing necrosis in moderately resistant $C$. arabica variety Pretoria on the third week after inoculation with C. kahawae isolate KM27 (x400). (B) Extensive mycelial growth in a susceptible reaction between moderately resistant variety K7 and isolate KM22. (x200). (C) Distorted hyphum (h) with short thick walled cells in moderately susceptible variety Mundo Novo inoculated with KM22 (x1000) (pcw is the plant cell wall). (D) Cell death at infection point on resistant variety Rume Sudan two weeks after inoculation with KM22 (x400).

(A) Colonisation par les extrémités des hyphes, des tissus proches de la surface en cours de nécrose, chez C. arabica variété Pretoria, moyennement résistante, 3 semaines après inoculation artificielle avec C. kahawae (isolat KM27)(x400). (B) Développement mycélien abondant dans une réaction susceptible entre la variété K7, moyennement résistante et l'isolat KM22 (x200). (C) Hyphe déformé, constitué de cellules courtes aux parois très fines, induit par la réaction de la variété moyennement sensible Mundo Novo, vis-à-vis de KM22 (x1000). (D) Mort cellulaire au point d'infection de la variété résistante Rume Sudan, deux semaines après inoculation avec KM22 (x400). 

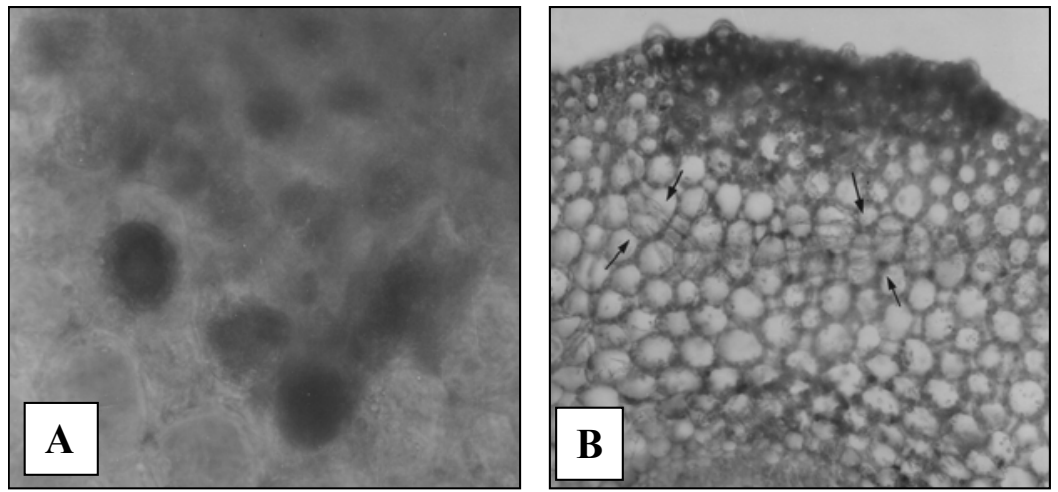

Figure 2 : Early cellular and tissue resistance responses to infection.

Réaction de résistance précoce des cellules et des tissus à l'infection.

(A) Dark cytoplasmic material in cells at the periphery of infected area (I. A) in moderately resistant variety Hibrido de Timor on the third week after inoculation with C. kahawae isolate KM29 (x400); (B) rudimentary cork barrier (between the arrows) below infected tissue in Hibrido de Timor in the third week after inoculation with KM22 (x100).

(A) Réaction cytoplasmique (noircissement) à la périphérie des cellules infectées (I. A) de la variété moyennement résistante Hibrido de Timor, 3 semaines après inoculation avec l'isolat KM29 (x400). (B) Barrière liégeuse sous-jacente (entre des flèches) aux tissus infectés de I'hybride de Timor, variété résistante, 3 semaines après inoculation avec l'isolat KM22 (x100)
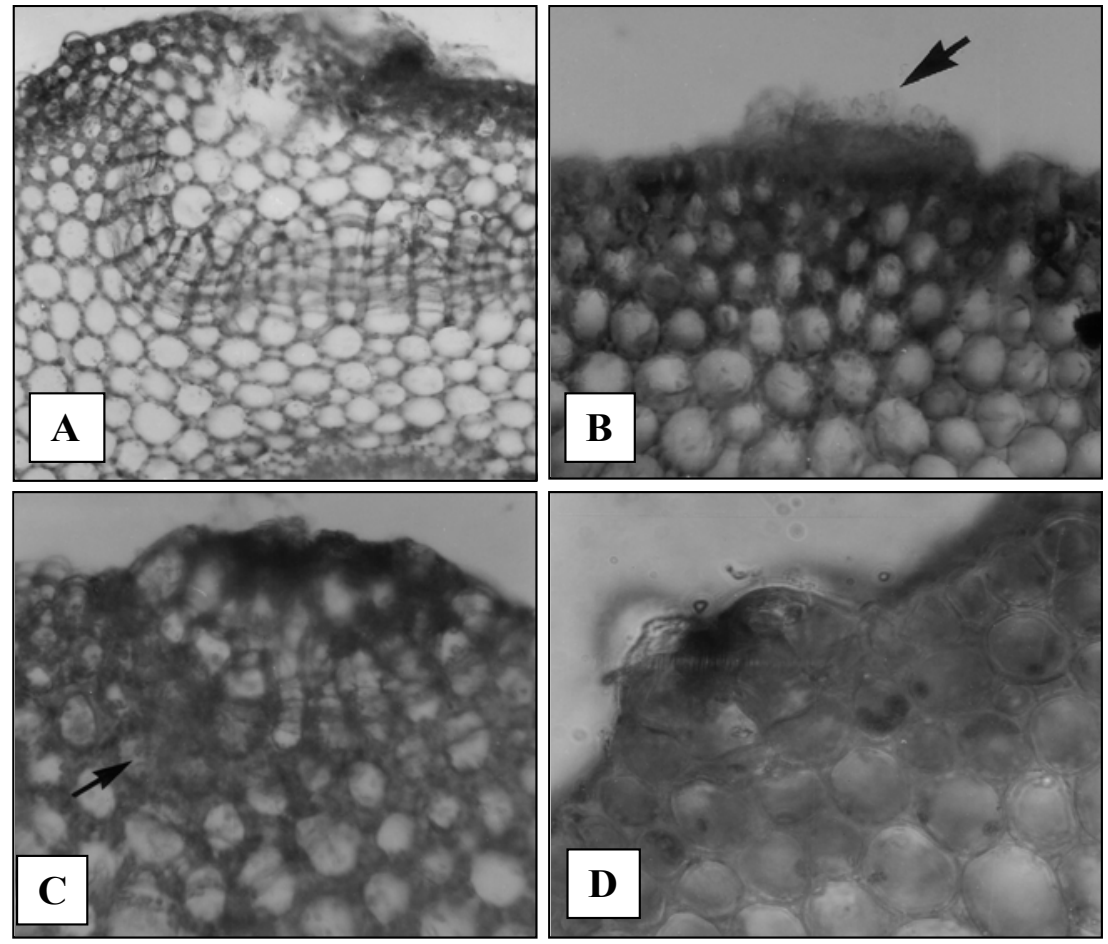

Figure 3 : Advanced host - pathogen interactions.

\section{Réactions de résistance.}

(A) Fully developed type B barrier in moderately resistant $C$. arabica variety Pretoria in the seventh week after inoculation with KM22 (x100). (B) Acervulus on infected tissue with restricted infection and necrosis in Hibrido de Timor on the third week after inoculation with C. kahawae KM22 (x100). (C) Penetration of a barrier in moderately resistant variety Geisha 10 in the fourth week after inoculation with KM22 causing necrosis on centre left (x200). (D) a minute scab on Robusta coffee hypocotyl on the fourth week after inoculation with KM27 (x400).

(A) Présence d'une barrière liégeuse (type B) développée par la variété Pretoria, modérément résistante, 7 semaines après inoculation artificielle de l'isolat de C. kahawae, KM22 (x100). (B) Apparition d'acervules de très petite taille sur des tissus nécrosés de l'hybride de Timor, 3 semaines après inoculation de l'isolat KM22 (x100). (C) Passage de la barrière liégeuse par les hyphes, $4^{e}$ semaine après l'inoculation, dans l'interaction entre la variété moyennement résistante Geisha 10 et l'isolat KM22, entraînant une dégradation des cellules situées au centre gauche (x200). (D) Mise en place d'une petite réaction de dépôt sur hypocotyle de caféier robusta, 4 semaines après inoculation avec l'isolat KM27 (x400). 
Table 1 : Percentage of hypocotyls out of fifty with fully developed type B barriers under inactive lesions in moderately resistant and resistant varieties on the eighth week after inoculation with three isolates of Colletotrichum kahawae in the laboratory.

Pourcentage d'hypocotyles sur cinquante présentant une barrière liégeuse totalement développée de type $B$, sous des lésions inactives, dans le cas de variétés résistantes et moyennement résistantes de C. arabica, 8 semaines après inoculation artificielle en conditions contrôlées, avec trois isolats de Colletotrichum kahawae

\begin{tabular}{lccc}
\hline \multirow{2}{*}{ Variety } & \multicolumn{3}{c}{ Isolates } \\
\cline { 2 - 4 } & KM22 & KM27 & KM29 \\
\hline K7 & 42 & 15 & 64 \\
Hibrido de Timor & 66 & 56 & 54 \\
Pretoria & 52 & 22 & 48 \\
Rume Sudan & 30 & 2 & 16 \\
Geisha 10 & 88 & 90 & 94 \\
Mundo Novo & 90 & 94 & 84 \\
\hline
\end{tabular}

\section{DISCUSSION}

In any one pathosystem, there can be various strategies of infection and resistance in different combinations and magnitudes depending on genotypes and environmental (external and internal) conditions. Coffee and Colletotrichum kahawae association has many factors affecting susceptibility and operates at all stages of pathogenesis from conidial germination to sporulation of the fungus (Mwang'ombe and Shanker, 1994 ; Gichuru, 1997). By reducing conidial germination and appresoria formation, CBD resistant coffee genotypes are able to reduce infection sites, as observed in this study. This gives the resistant cultivars further advantage in that mobile resistance factors (biochemical) will be concentrated into fewer areas, resulting in higher concentrations per infection site, even when initial quantities are similar to those in susceptible cultivars.

Fungal growth in the coffee tissues varied from rapid extensive growth in living tissues (with distinct organelles), slow retarded growth with distorted hyphae in normal cells, late hyphal death, to early death in hypersensitive manner. These observations show the presence of toxic compounds of at least two categories. The distorted hyphal growth in normal cells may indicate preferential toxicity to the fungus, while death of both hyphae and infected cells indicate toxicity to both fungi and plant cells. The compounds that cause cytoplasmic changes and cell death ahead of hyphal infection, and the brown crust on Robusta coffee are likely to belong to the second category. Similar hostpathogen complexes have been reported in barley-Erysiphe graminis hordei (Kunoh et al., 1982 ; Carver, 1986 ; hop - Sphaerotheca humuli (Godwin et al., 1987), Oilseed rapeLeptosphaeria maculans (Hammond and Lewis, 1987) poplar-Melampsora larici-populina (Laurans and Pilate, 1999) associations. The existence of fungitoxic compounds in coffee has been reported before (Gichuru, 1997). These are both performed and induced by infection. The brown crust formed on attached Robusta coffee berries could be due to hypersensitivity of epidermal cells. The pathogen could also be restricted by starvation. This could also be achieved by observed cell death at the periphery of infected area and the formation of cork barriers. These mechanisms would eliminate biotrophic associations with pathogen and block nutrient transfer to the infected area. It was observed that where the pathogen developed to sporulation, no cork barriers were formed or were rudimentary (Figure $3 \mathrm{~A}$ ). The occurrence of responses to infection, ahead of the hyphae, demonstrated the existence of elicitors which it is desirable to investigate further.

Formation of cork barriers was observed in all varieties of Arabica coffee tested, as was also found by Masaba and Van der Vossen (1982). However, there were differences in their elaborate appearance. It seemed that their initiation and degree of development was related to the extent of the infection. Type A barriers (under raised scabs) were associated with high resistance, 
causing early cessation of pathogen growth, while type $B$ (under sunken lesions) were associated with lower resistance. Reaction types may be categorised as: (i) high resistance, dominated by small type $A$ barriers, (ii) moderate resistance, with both types $A$ and $B$ barriers in almost equal proportions, but type $A$ barriers mostly bigger than in the previous category, (iii) moderately susceptibility dominated by type $B$ barriers, and (iv) high susceptibility without the barriers, except rarely type B when environmental conditions do not favour disease progress. Data by Masaba and Van der Vossen (1982) supports this argument. It is also possible that on a particular genotype, different isolates of the pathogen might induce the development of different types of cork barriers depending on their aggressiveness. This was also shown by results in Table 1, but further detailed studies are required, especially if clonal hypocotyls can be developed.

Retardation or cessation of pathogen growth is necessary to allow time for the barrier to develop to effective level. Resistant varieties are inherently able to do this but susceptible ones are not unless assisted by the environment (Masaba and Van der Vossen, 1982). The observed penetration of cork barrier might be due to the ability of the fungus to overcome the resistance mechanisms, or that particular genotype was not able to respond adequately. This observation raises the concern over the possibility of existence or development of races of pathogen, although Omondi et al. (2000) explained the current variation observed in Kenya as due to aggressiveness. Hammond and Lewis (1987) however, observed penetration of a barrier in one variety of Brassica napus var oleifera by an aggressive isolate but was arrested in the second cycle of resistance reactions.

\section{CONCLUSION}

The study show that environmental conditions, especially temperature and relative humidity are key factors in infection and resistance expression. Since in the field these conditions are variable, it may explain why Geisha 10 formed more effective barriers under field than laboratory where conditions are regulated to favour the disease. While the ability to form barriers per se is universal within varieties to slow and/or kill the pathogen was or not effective, probably due to inadequacy or in time biosynthesis of fungitoxic compounds. The universal formation of cork barriers can mean that the corks have other functions like healing of wounds, and therefore, not likely to be pathogen-specific. It can be deduced that under optimum conditions for the disease, it is the effectiveness of the other supporting mechanisms that make the difference between susceptibility and resistance, contrary to the fact that the formation of cork barriers is the main determinant of resistance. However, cork barrier together with dead cells above them are the terminal block to pathogen progress if some other compounds do not kill or block it earlier. The plant may not need to form very elaborate barriers if the pathogen is killed early as in type A scabs. This may also indicate the existence of other factors such as fungitoxic compounds and elicitors that induce reactions beyond hyphal tips. Further investigations of the biochemical aspects of this host-pathogen- interaction are recommended.

\section{ACKNOWLEDGEMENTS}

I wish to thank Ms. J. W. Thuku, Ms. C. W. Ngugi, Mr. M. M. Miheso and Mr. S. M. Nyoro for their devoted assistance during the study, the European Union for financial assistance through contract number TS3-CT 94-0307 and the Director of Research, Coffee Research Foundation for permission to publish this paper.

\section{REFERENCES}

Bettencourt A. 1973. Consideraçoes gerais sobre o «Hibrido de Timor». Instituto Agronomico de Campinas, Circular $N^{\circ} 31$, Campinas, Brazil : $20 \mathrm{p}$.

Carver T. L. W. 1986. Histology of Infection by Erysiphe graminis f.sp hordei in spring barley lines with various levels of partial resistance. Plant Path. 35 : 232 - 240.

Gichuru E. K. 1997. Resistance mechanisms in Arabica coffee to coffee berry disease (Colletotrichum kahawae Sp. Nov.) - A review. Kenya Coffee, 62 (737) : 2441 - 2444. 
Godwin J. R., J. W. Mansfield and P. Darby. 1987. Microscopical studies of resistance of powdery mildew disease in the hop cultivar Wye Target. Plant Path. $36: 21$ - 32.

Griffiths E., J. N Gibbs and J. M. Waller. 1971. Control of coffee berry disease. Ann. Appl. Bio. $67: 45$ - 74

Hammond K. E. and B. G. Lewis. 1987. Variations in stem infections caused by aggressive and non-aggressive isolates of Leptosphaeria maculans on Brassica napus var. Oleifera. Plant Path. 36 : 53 - 65.

Kunoh H., K. Yamamori and H. Ishizaki. 1982. Cytological studies of early stages of powdery mildew in barley and wheat. VIII Autofluorescence at penetration sites of Erysiphe graminis hordei on living barley coleoptiles. Physio. PI. Path. 21 : $373-379$.

Laurans F. and G. Pilate. 1999. Histological aspects of a hypersensitive response in poplar to Melampsora larici - populina. Phytopath. $89: 233$ - 238.

Masaba D. M. and H. A. M. Van der Vossen. 1982. Evidence of cork barrier formation as a resistance mechanism to berry disease
(Colletotrichum coffeanum) in Arabica coffee. Neth. J. PI. Path. $88: 19-32$.

Masaba D. M. and J. M. Waller. 1992. Coffee berry disease: the current status. In : J. A. Bailey and $M$. J. Jeger (Eds.). Colletotrichum : Biology, pathology and control. C.A.B.I International, Wallingford, UK : pp $237-249$.

Mwang'ombe A. W. and M. Shanker. 1994. Prepenetration events and sporulation of Colletotrichum kahawae Waller and Bridge (Syn. Colletotrichum coffeanum Noack) on different cultivars of Coffea arabica. E. Afr. Agric. For. J. 59 (4) : 327 - 336.

Omondi C. O., P. O. Ayiecho, A. W. Mwang'ombe and $\mathrm{H}$. Hindorf. 2000. Reaction of some Coffea arabica genotypes to strains of Colletotrichum kahawae, the cause of Coffee Berry Disease. J. Phytopath. 148 : $61-63$.

Van der Vossen H. A. M., R. T. A. Cook and G. N. W. Murakaru. 1976. Breeding for resistance to coffee berry disease caused by Colletotrichum coffeanum Noack (sensu Hindorf) in Coffea arabica L. I. Methods of pre-selection for resistance. Euphytica $25: 733$ - 745. 